\title{
ADDITIONS TO THE DISTRIBUTION OF OPISTHOBRANCHIA IN THE TURKISH AEGEAN COASTS
}

\author{
Ali TÜRKER, Faculty of Fisheries, Muğla Sitkı Koçman University/Turkey, aliturker@mu.edu.tr \\ (iD) https://orcid.org/0000-0002-6299-1087) \\ Ferhat YALGIN, Faculty of Fisheries, Muğla Sıtkı Koçman University/Turkey, ferhatyalgin@gmail.com \\ (iD) https://orcid.org/0000-0002-0027-5114) \\ *Sercan YAPICI, Faculty of Fisheries, Muğla Sitkı Koçman University/Turkey, sercanyapici@mu.edu.tr \\ (iD) https://orcid.org/0000-0003-2288-5084)
}

Received: 11.09.2019, Accepted: 28.11.2019

*Corresponding author

Research Article

DOI: $10.22531 /$ muglajsci.618588

\section{Abstract \\ In the present study, native and alien opisthobranch species observed via SCUBA diving along Turkish Aegean coasts have been represented: In the Turkish Aegean coasts, Goniobranchus annulatus was first observed while Luisella babai, Coryphellina rubrolineata, Felimare picta, and Felimida luteorosea were northwardly expanded their distribution. Keywords: Mollusca, Aegean Sea, native species, non-native species, range expansion \\ TÜRK EGE KIYILARINDAKİ OPISTHOBRANCHIA'NIN DAĞILIMINA KATKILAR}

Öz

Bu çalışmada, Türk Ege Denizi kıyılarında SCUBA dalışları ile gözlemlenen yerli ve yabancı opisthobranch türleri sunulmuştur: Türk Ege klyılarında Goniobranchus annulatus ilk kez gözlenirken, Luisella babai, Coryphellina rubrolineata, Felimare picta ve Felimida luteorosea dağılımlarını kuzey yönlü olarak genișletmişlerdir.

Anahtar Kelimeler: Mollusca, Ege Denizi, yerli tür, yabancı tür, dağılım genişlemesi

Cite

Türker, A., Yalgın, F., Yapıcı, S., (2020). "Addition to the Distribution of Opisthobranchia in the Turkish Aegean Coasts", Mugla Journal of Science and Technology, 6(1), 27-31.

\section{Introduction}

The Mediterranean Sea and adjacent seas are considered to be the main hotspots of marine bioinvasion caused by tropical and/or sub-tropical origin marine organisms $[1,2]$. Alien marine biota in the Mediterranean consist of 986 alien species including fish, zoobenthos (Polychaeta, Crustacea, Mollusca, Echinodermata, Sipuncula, Bryozoa and Ascidiacea) phytobenthos, phytoplankton and zooplankton [2]. Climate change has been caused poleward and deeper distributional shifts for native species whilst the northward range shift for tropical alien species. 3000 species of nudibranch mollusk found throughout the world's oceans while 87 native and more than 20 alien nudibranchs have been recorded in Turkish Seas until now $[3,4]$. The aim of this study provide a new data about distributional shifts of native and non-native opisthobranchs from the the Aegean Sea.

\section{Material and Methods}

\subsection{Non-native species}

Goniobranchus annulatus

On 26 September 2018, a single specimen of G. annulatus was observed and photographed by a SCUBA diver in
Foça $\left(38^{\circ} 4473^{\prime} \mathrm{N}, 26^{\circ} 4613^{\prime} \mathrm{E}\right)$ at a depth of $9 \mathrm{~m}$. The specimen was identified using high-quality photos as in Yonow 2008 [5].

Coryphellina rubrolineata

On 05 September 2018, a single specimen of $C$. rubrolineata was observed and photographed by a SCUBA diver at a depth of $16 \mathrm{~m}$ near the Lundy Wreck in Çanakkale $\left(40.1133^{\circ} \mathrm{N}, 26.2177^{\circ} \mathrm{E}\right)$. The specimens were identified using high-quality photos as in and Yonow 2008 [5].

\subsection{Native species}

Felimida luteorosea

On 02 October 2018, a single specimen of F. luteorosea was found and photographed by a SCUBA diver at a depth of $18 \mathrm{~m}$ near the HMS Majestic Wreck in Çanakkale Strait ( $\left.40^{\circ} 1100^{\prime} \mathrm{N}, 26^{\circ} 2203^{\prime} \mathrm{E}\right)$. The specimen was identified using high-quality photos as in Rudman 2001 [6].

Luisella babai \& Felimare picta

On 21 May 2018, a specimen of L. babai and F. picta were detected and photographed by a SCUBA diver at a depth of $18 \mathrm{~m}$ near Monem Wreck in Izmir $\left(38.2358^{\circ} \mathrm{N}\right.$, $26.1636^{\circ} \mathrm{E}$ ). The specimen was identified using highquality photos as in Rudman 2001 [6]. 


\section{Goniobranchus annulatus}

\section{Results and Discussion}

Systematics

Phylum: Mollusca

Class: Gastropoda

Family: Chromodorididae Bergh, 1891

Genus: Chromodoris Alder \& Hancock, 1855

Goniobranchus annulatus (Eliot, 1904) [Figure 2]

Synonyms: Chromodoris annulata Eliot, 1904

Glossodoris annulata (Eliot, 1904)

Diagnostic characteristics: The body is white with large, raised, orange yellow pustules and two purple rings enclosing the rhinophores and gills. These orange yellow spots are also present on the foot and can be variable in number. The margin is purple, the gills and rhinophores are white edged in purple. A juveniles have fewer gills than adults.

Distribution: G. annulatus is found in the Red Sea, Arabian Gulf, and western Indian Ocean. Its first Mediterranean report was given from Saronikos Gulf [7]. Thereafter, it is reported by various authors along Levantine coasts $[8,9,10,11,12,13]$. This finding provides its northernmost observation in the Hellenic and Turkish Aegean coasts [Figure 1].

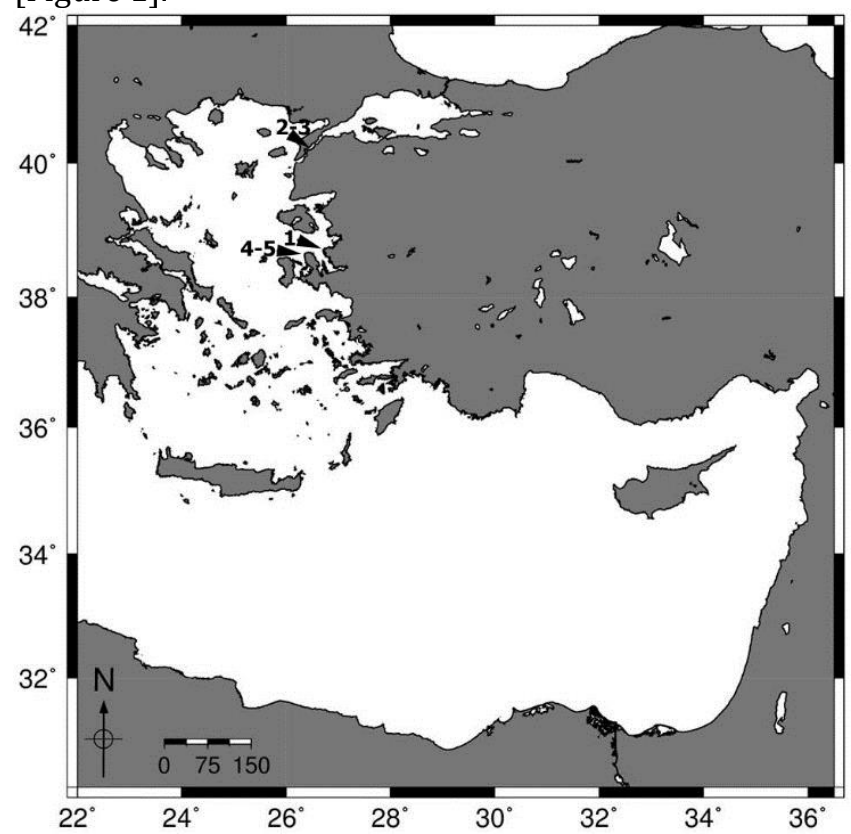

Figure 1. The observations of opisthobranchs along Turkish Aegean coasts: 1) Goniobranchus annulatus, 2-3) Coryphellina rubrolineata \& Felimida luteorosea, 4-5) Luisella babai \& Felimare picta

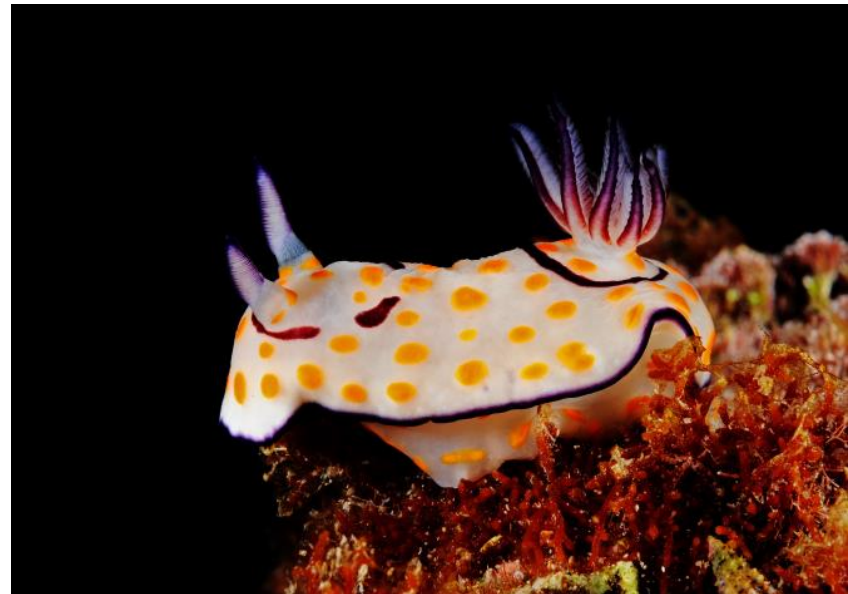

Figure 2. An underwater observation of $G$. annulatus Coryphellina rubrolineata

Systematics

Phylum: Mollusca

Class: Gastropoda

Family: Flabellinidae Bergh, 1889

Genus: Coryphellina O'Donoghue, 1929

Coryphellina rubrolineata O'Donoghue, 1929 [Figure 3] Synonyms: Flabellina rubrolineata (O'Donoghue, 1929) Diagnostic characteristics: The creamy white body has three magenta violet stripes down its length. Similar colour bands exist on the cerata, and the propodial and oral tentacles. The rhinophores are papillate only on their posterior sides, and magenta on the anterior faces. The dark contents of the cerata can be visible in some specimens, and the tips of the cerata are golden yellow or orange.

Distribution: $C$. rubrolineata is common in the IndoPasific regions. It is first reported from Israeli coast [14]. Thereafter, it is reported from Levantine Sea $[15,16]$ and then it has established populations throughout the and Aegean coasts $[17,18]$ This observation represents its northernmost observation in the Turkish Aegean coasts [Figure 1].

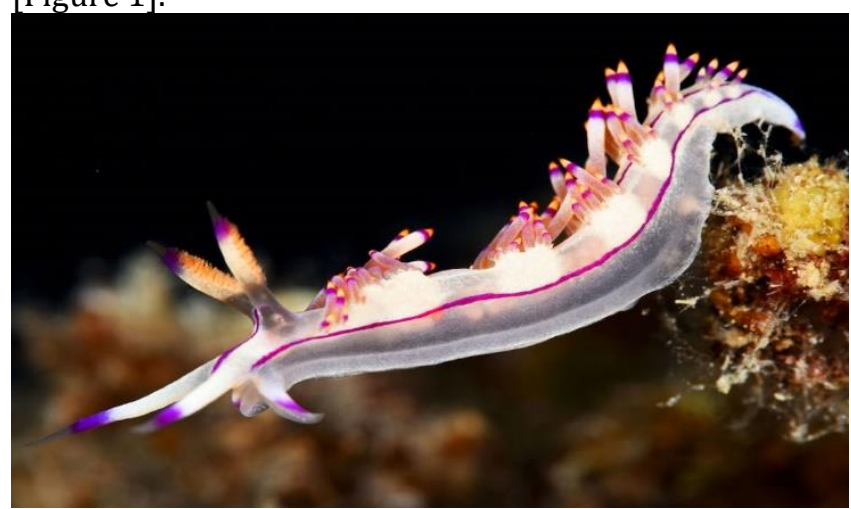

Figure 3. An underwater observation of C. rubrolineata Felimida luteorosea

Systematics

Phylum: Mollusca

Class: Gastropoda

Family: Chromodorididae Bergh, 1891

Genus: Felimida Ev. Marcus, 1971 
Felimida luteorosea (Rapp, 1827) [Figure 4]

Synonyms: Chromodoris iheringi Bergh, 1879

Chromodoris luteorosea (Rapp, 1827)

Doris luteorosea Rapp, 1827

Diagnostic characteristics: The distinctive purple color body is covered yellow spot and has a yellow-edged mantle. The rhinophores are reddish-brown while gills are a translucent color.

Distribution: It spreads along with the western sectors of Mediterranean and nearby Atlantic coast of Spain and Portugal. Its first report of Aegean and Levantine coasts in the Turkey were given by $[19,20]$ respectively. This observation provides its northernmost observation in the Turkish Aegean coasts [Figure 1].

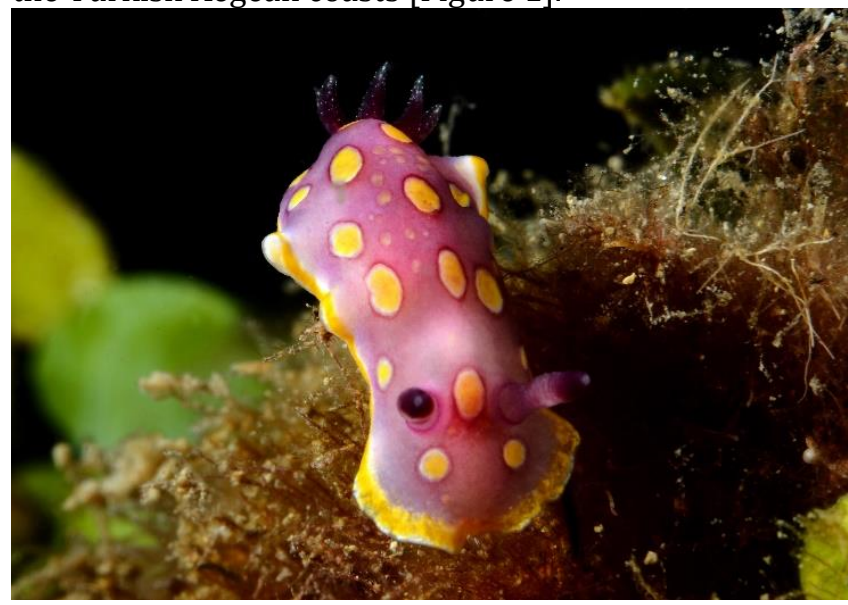

Figure 4. An underwater observation of F. luteorosea

\section{Luisella babai}

Systematics

Phylum: Mollusca

Class: Gastropoda

Family: Samlidae Korshunova, Martynov, Bakken, Evertsen, Fletcher, Mudianta, Saito, Lundin, Schrödl \& Picton, 2017

Genus: Luisella Korshunova, Martynov, Bakken, Evertsen, Fletcher, Mudianta, Saito, Lundin, Schrödl \& Picton, 2017

Luisella babai (Schmekel, 1972) [Figure 5]

Synonyms: Flabellina babai Schmekel, 1972

Diagnostic characteristics: Its color is mainly white to light blue. The elongated body is ended with a translucent long sharp-pointed tail. Cerata are formed with groups of 3-9. All individuals have yellow-orange rings on the their terminal parts. The anterior part is a similar color to the body. The upper part of the two rhinophores has a yellow color.

Distribution: It is considered as common species in the Mediterranean Sea. It spreads from the Adriatic Sea to the Atlantic coasts of Spain, Portugal and Senegal. Its first record in the Mediterranean coast of Turkey was given from Levantine coasts [21]. This finding reports its northernmost observation in the Turkish Aegean coasts [Figure 1].

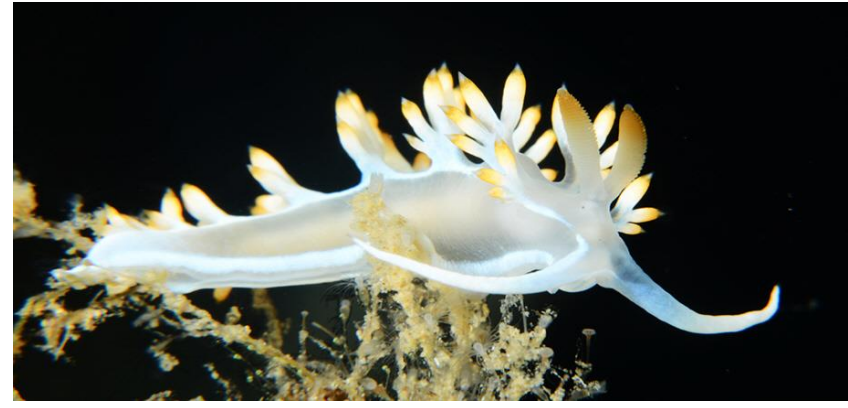

Figure 5. An underwater observation of F. babai

\section{Felimare picta}

Systematics

Phylum: Mollusca

Class: Gastropoda

Family: Chromodorididae Bergh, 1891

Genus: Felimare Eveline \& Ernst Marcus 1967

Felimare picta (Philippi, 1836) [Figure 6]

Synonyms: Doris picta Philippi, 1836

Diagnostic characteristics: A colour differences exist between Atlantic and Mediterranean populations. The background color of body is mainly dark blue. This color is almost black in Atlantic populations, while in the Mediterranean populations are generally discolored, however, some specimens could be pale blue, somewhat violet. The yellow coloration of the dorsum comprises of three more or less discontinuous lines that end in the branchial orifice, The number of yellow spots between dorsal lines increases as the animal grow. The rhinophores of specimens belonging to the Mediterranean are uniformly colored, usually, are violet blue.

Distribution: F. picta presents the wider distribution area throughout the Mediterranean. Its northernmost report in the Aegean coasts of Turkey was given from Datça [19] This recent data represents its new northernmost observation in the Turkish Aegean coasts [Figure 1].

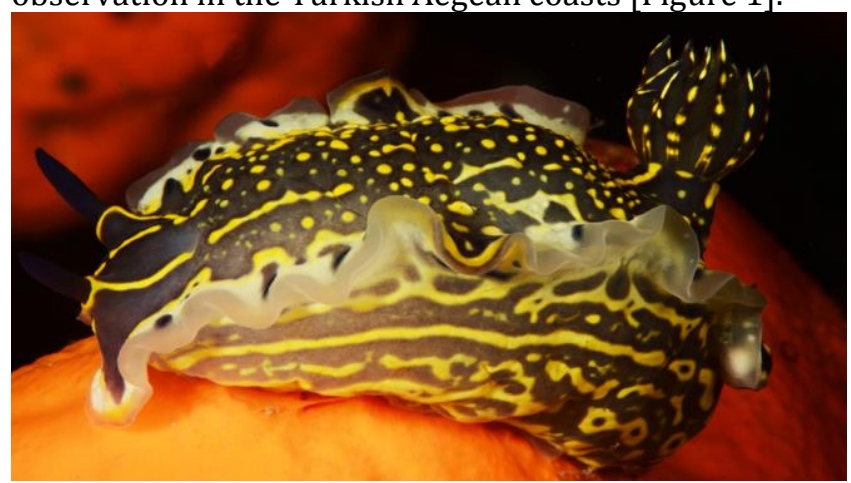

Figure 6. An underwater observation of $F$. picta

In conclusion, several vectors including global warming, intensive maritime transport cause native and nonnative thermophilic species belonging to various taxa to expand their range. Most of nudibranch mollusks prefer warm water. Consequently, the distribution of these species should mandatorily monitor via formal and citizen science because poleward distributions of these species are an indication of elevated sea surface 
temperature and possible future range shift/range expansion of thermophilic native and non-native species.

\section{Acknowledgment}

Authors would like to thank Bedri Sincar for providing photos.

\section{References}

[1] Rilov, G. and Galil, B.S., "Marine bioinvasions in the Mediterranean Sea - history, distribution and ecology" Biological Invasions in Marine Ecosystem, Springer, Berlin, 549-576, 2009.

[2] Zenetos, A., Gofas, S., Morri, C., Rosso, A., Violanti, D., Gracia-Raso, J.E., Cinar, M.E., Almogi-Labin, A., Ates, E., Azzurro E., Ballesteros, E., Biachi, C.N., Bilecenoglu, M., Gambi, M.C., Giangrande, A., Gravili, C., Hyams-Kaphzan, O., Karachle, P., Katsanevakis, S., Lipej, L., Mastrototaro, F., Mineur, F., Pancucci, M.A., Papadopoulou, M.A., Ramos-Espla, A., Salas, C., San Martin, G., Sfriso, A., Streftaris, M. and Velarque, M., "Alien species in the Mediterranean Sea by 2012. A contribution to the application of European Union's Marine Strategy Framework Directive (MSFD). Part 2. Introduction trends and pathways" Mediterranean Marine Science, 13: 328-352, 2012.

[3] Çınar, M.E., Bilecenoğlu, M., Öztürk, B. and Can, A., "New records of alien species on the Levantine coast of Turkey" Aquatic Invasions, 1(2): 84-90, 2006.

[4] Öztürk, B., Doğan, A., Bitlis-Bakır, B. and Salman, A., "Marine molluscs of the Turkish coasts: an updated checklist" Turkish Journal of Zoology, 38: 832-879, 2014.

[5] Yonow, N., "Sea Slugs of the Red Sea" Pensoft, Sofia Moscow, 2008.

[6] Rudman, W.B., "Sea Slug Forum" Australian Museum, Sydney. $\quad$ Retrieved from http://www.seaslugforum.net/factsheet/pleugran, 2001.

[7] Zenetos, A., Koutsoumbas, D. and Vardala-Theodorou, E., "Origin and vectors of introduction of exotic molluscs in Greek Waters" Belgian Journal of Zoology, 135(2): 279-286, 2005.

[8] Çevik, C. and Ergüden, D., "İskenderun Körfezinde Dağilim Gösteren Bazi Opisthobranchia Türleri”, II. Ulusal Malakoloji Kongresi, Adana, Türkiye, 2008.

[9] Gökoglu, M. and Özgur, E., "First report of Chromodoris annulata Eliot, 1904 (Mollusca, Opisthobranchia, Chromodorididae) on the Levantine coast of Turkey, Eastern Mediterranean" Aquatic Invasions, 3: 435-437, 2008.

[10] Yokeş, M.B., Balikçi, Ö., Karhan, Ü.S. and Dalyan, C. "An established population of Chromodoris annulata on the Mediterranean coast of Turkey (Opisthobranchia, Gastropoda)" Triton, 19: 12-14, 2009.

[11] Özcan, T., Ergüden, D., Turan, C. and Çevik, C. "Distribution of alien nudibranch Chromodoris annulata Eliot, $1904 \quad$ (Opisthobranch; Chromodorididae) in the Gulf of Iskenderun, Turkey" Biharean Biologist, 4(1): 89-90, 2010.
[12] Tsiakkiros, L., "Re: Chromodoris annulata from the Mediterranean coast of Israel. [Message in] Sea Slug Forum. Australian Museum, Sydney. http://www.seaslug forum.net/find/23027", 2010.

[13] Pasternak, G., Ziv, R., Eyal, G., Shefer, S., Mienis, H.K., Rittner, O. and Galil, B.S., "On the population of Chromodoris annulata Eliot, 1904 (Mollusca: Opistobranchia: Chromodorididae) off the Mediterranean coast of Israel" Aquatic Invasions, 6(1): 91-93, 2011.

[14] Gat, G., “Flabellina rubrolineata (O’Donoghue) and Phidiana indica (Bergh) (Nudibranchia Aeolidioidea), two new Lessepsian immigrant Eastern Mediterranean" Journal of Molluscan Studies, 59: $120,1993$.

[15] Yokeș, M.B. and Rudman, W.B., "Lessepsian opisthobranchs from southwestern coast of Turkey; five new records for Mediterranean" Rapport Commission International pour l'exploration scientifique de la Mer Mediterranée, Monaco, 2004a, 37: 557 .

[16] Crocetta, F., Zibrowius, H., Bitar, G., Templado, J. and Oliverio, M., "Biogeographical homogeneity in the eastern Mediterranean Sea - I: the opisthobranchs (Mollusca: Gastropoda) from Lebanon" Mediterranean Marine Science, 14(2): 403-408, 2013.

[17] Eleftheriou, A., Anagnostopoulou- Visilia, E., Anastasopoulou, E., Ateş, S.A., El. I Bachari, N., Cavas, L., Cevik, C., Ulha, M., Cevik, F., Delos, A.-L., Derici, O.B., Erguden, D., Fragopoulu, N., Giangrande, A., Göksan, T., Gravili, C., Gurlek, M., Hattour, A., Kapiris, K., Kouraklis, P., Lamouti, S., Prato, E., Papa, L., Papantoniou, G., Parlapiano, I., Poursanidis, D., Turan, C. and Yaglioglu, D., "New Mediterranean biodiversity records (December 2011)" Mediterranean Marine Science, 12, 491-508, 2011.

[18] Kapiris, K., Apostolidis, C., Baldaccini, R., Başusta, N., Bilecenoglu, M., Bitar, G., Bobori, D.C., Boyaci, Y.Ö., Dimitriadis, C., Djurović, M., Dulčić, J., Durucan, F., Gerovasileious, V., Gökoğlu, M., Koutsoubas, D., Lefkaditou, E., Lipej, L., Marković, O., Mavrić, B., Özvarol,Y., Pesic, V., Petriki, O., Siapatisi, A.M., Sini, M., Tibull D. and Tiralongo, F., "New Mediterranean Marine biodiversity records (April, 2014)" Mediterranean Marine Science, 15(1): 198-212, 2014.

[19] Okuş, E., Sur, H.İ., Yüksek, A., Yılmaz, İ.N., AslanYılmaz, A., Karhan, S.Ü., Öz, İ., Demirel, N., Taş, S., Altıok, A. Müftüoğlu, A.E., Gazioğlu, C., Yücel, Z.Y., Demir, V., Zeki, S. and Tural, U., "Datça-Bozburun Özel Çevre Koruma Bölgesinin Denizsel ve Kiyısal Alanlarının Biyolojik Çeşitliliğinin Tespiti Projesi. Final Raporu" T.C. Çevre ve Orman Bakanlığı Ankara, 2004.

[20] Yokeş, M.B., "Additions to the Knowledge of Opisthobranchia from Turkey" Triton, 20: 5-19, 2009. 
[21] Yokeș, M.B. and Rudman, W.B., "Türkiye sularında tespit edilen Aeolidiina (Opisthobranchia, Gastropoda) türleri; Türkiye için 11 yeni kayıt" 8 . Sualtı Bilim ve Teknolojisi Toplantisl; Sabancl Üniversitesi, İstanbul, 2004b, 60-69. 